\title{
Hubungan antara struktur lanskap dan keanekaragaman Hymenoptera parasitoid: Sebuah model interaksi pada pertanaman kacang panjang
}

\author{
Relationship between landscape structure and Hymenoptera diversity: \\ An interaction model on long bean fields
}

\author{
Tazkiyatul Syahidah ${ }^{{ }^{*}}$, Akhmad Rizali ${ }^{2}$, Lilik Budi Prasetyo ${ }^{3}$, Pudjianto ${ }^{1}$, \\ Damayanti Buchori ${ }^{1,4}$ \\ ${ }^{1}$ Departemen Proteksi Tanaman, Fakultas Pertanian, IPB University \\ Jalan Kamper, Kampus IPB Dramaga, Bogor 16680 \\ ${ }^{2}$ Jurusan Hama dan Penyakit Tumbuhan, Fakultas Pertanian, Universitas Brawijaya \\ Jalan Veteran, Malang 65145 \\ ${ }^{3}$ Departemen Konservasi Sumberdaya Hutan dan Ekowisata, Fakultas Kehutanan dan \\ Lingkungan, IPB University, Jalan Meranti, Kampus IPB Dramaga, Bogor 16680 \\ ${ }^{4}$ Center for Transdisciplinary and Sustainability Science (CTSS), IPB University \\ Kampus Baranangsiang, Bogor 16127
}

(diterima Juni 2019, disetujui Januari 2021)

\begin{abstract}
ABSTRAK
Struktur lanskap agroekosistem, baik itu komposisi dan konfigurasinya, dapat memengaruhi keberadaan predator dan parasitoid, serta keefektifan pengendalian hayati. Penelitian ini bertujuan untuk mempelajari hubungan struktur lanskap terhadap keanekaragaman Hymenoptera parasitoid pada pertanaman kacang panjang di Bogor, Jawa Barat. Sebanyak enam lahan pertanaman kacang panjang dipilih dan dilakukan kuantifikasi lanskap dalam radius $500 \mathrm{~m}$ dari lahan kacang panjang. Di setiap lahan, sampling Hymenoptera parasitoid dilakukan pada plot berukuran $50 \mathrm{~m}$ x $25 \mathrm{~m}$ dengan menggunakan metode koleksi langsung. Hasil koleksi diperoleh 283 individu Hymenoptera parasitoid, yang terdiri atas 9 famili dan 31 spesies. Berdasarkan uji Mantel, struktur lanskap tidak menunjukkan hubungan dengan komposisi dari parasitoid dalam lahan kacang panjang. Walaupun demikian, pada skala kelas lanskap, komposisi lanskap meliputi lahan pertanian dan pepohonan mempengaruhi kelimpahan parasitoid. Lanskap pertanian dengan jumlah fragmen (patch) lahan pertanian yang tinggi cenderung memiliki kelimpahan parasitoid yang tinggi. Hal tersebut menunjukkan bahwa komposisi lanskap pada skala klas lebih berpengaruh terhadap Hymenoptera parasitoid, dibandingkan skala lanskap.
\end{abstract}

Kata kunci: Bogor, pengendalian hayati, skala klas, skala lanskap

\begin{abstract}
The structure of agricultural landscape, both of its composition and configuration can affect the presence of predators and parasitoids, and influence the effectiveness of biological control. This study was aimed to examine the relationship between landscape structure and the diversity of Hymenoptera parasitoids in long bean fields in Bogor, West Java. In total, six long bean fields
\end{abstract}

\footnotetext{
*Penulis korespondensi: Tazkiyatul Syahidah. Program Studi Entomologi, Sekolah Pascasarjana, IPB University

Jalan Kamper, Kampus IPB Dramaga, Bogor 16680, Tel/Faks: 0251-8425980, Email: tazkiyasyahidah@gmail.com
} 
were selected and quantified within a radius $500 \mathrm{~m}$ from long bean field. In each long bean field, Hymenoptera parasitoids were sampled in a $50 \mathrm{~m}$ x $25 \mathrm{~m}$ plot using direct observation. The research result found 283 individuals of Hymenoptera parasitoids belong to 9 families and 31 species. Based on the Mantel test, the landscape structure did not affect the species composition of parasitoids in long bean. However, at class scale, landscape composition especially crop field and semi-natural habitat have an effect on parasitoid abundance. Agricultural landscape with higher patch number of crop fields tends to have higher parasitoid abundance. It indicates that landscape composition at class scale is more affected to Hymenoptera parasitoids than at landscape scale.

Key words: Bogor, biological control, class scale, landscape scale

\section{PENDAHULUAN}

Struktur lanskap pertanian dapat memengaruhi keberadaan biodiversitas dan jasa lingkungan, seperti penyerbukan dan pengendalian hama (Susilawati et al. 2018; Ulina et al. 2019). Beberapa penelitian telah menunjukkan bahwa struktur lanskap dapat memengaruhi interaksi antara tanaman, hama, dan musuh alami, dan dapat memengaruhi keberhasilan atau kegagalan pengendalian hayati (Landis 1994). Beberapa komponen penting dalam struktur lanskap, seperti ukuran patch (fragmen), matrix (matriks), dan corridor (koridor) memiliki peran dalam menentukan tingkat kompleksitas sebuah lanskap (Prasetyo 2017). Fragmen adalah area homogen yang dapat dibedakan dari daerah sekelilingnya, matriks adalah fragmen yang mendominasi lanskap, sedangkan koridor adalah fragmen yang berbentuk memanjang, sebagai penghubung konektivitas antar fragmen. Fragmen-fragmen, matriks, dan koridor mempunyai peran penting sebagai habitat bagi organisme yang hidup di dalamnya. Berdasarkan pembentukannya fragmen dapat dibedakan menjadi fragmen yang terbentuk secara alami (environmental resource patch), terbentuk karena gangguan manusia (disturbance patch), dan fragmen penutupan lahan asli yang tersisa (remnant patch) karena matriks mengalami gangguan (Prasetyo 2017).

Lahan pertanian merupakan fragmen yang terbentuk karena ditanami tanaman pertanian, dengan areal di sekelilingnya berupa perumahan, tegakan pepohonan sisa (remnant trees) serta penutupan lahan lain membentuk struktur lanskap pertanian pedesaan. Semakin beragam struktur penyusun lanskap pertanian maka keanekaragaman lanskap pertanian semakin tinggi sehingga fungsi lanskap juga menjadi semakin kompleks, yang berkaitan dengan perpindahan materi dan energi, pergerakan spesies antar fragmen dan rantai makanan. Secara kuantitatif struktur dan dominansi lanskap dapat dihitung dengan menggunakan indeks lanskap (landscape indices), di antaranya luas fragmen (ha) (class area/CA), rata-rata luas fragmen (ha) (mean patch size/MPS), jumlah fragmen (buah) (number of patch/NumP), jumah total garis tepi dari fragmen sejenis (m) (total edge/TE) (McGarigal \& Marks 1995).

Pengaruh kompleksitas lanskap terhadap biodiversitas serangga cukup beragam. Ada beberapa studi yang menunjukkan kompleksitas lanskap pertanian dapat meningkatkan keanekaragaman dan kelimpahan serangga pengunjung bunga maupun musuh alami, bahkan seringkali dapat mengurangi kerusakan tanaman oleh hama (Chaplin-Kramer et al. 2011; Rizali et al. 2018; Ulina et al. 2019). Namun, ada penelitian yang menunjukkan bahwa kompleksitas lanskap tidak memengaruhi keanekaragaman musuh alami dan parasitisasinya (Costamagna et al. 2004). Ulina (2019) menyatakan bahwa kelimpahan Hymenopetera parasitoid meningkat pada struktur lanskap kompleks, walaupun ternyata interaksi parasitoid Apanteles dengan inangnya tidak dipengaruhi oleh kompleksitas lanskap. Tipe dan kualitas habitat, susunan spasial, danketerhubungan (connectivity) antar habitat juga telah terbukti dapat memengaruhi keanekaragaman hayati dan fungsi ekosistem Kruess \& Tscharntke (2000). Marino \& Landis (2000) serta Veres, (2013) lebih lanjut menyatakan bahwa struktur lanskap pertanian tidak hanya memengaruhi keanekaragaman musuh alami di dalam pertanaman, tetapi juga kelimpahan dan efektivitasnya. Kelimpahan dan laju parasitisme parasitoid dari Melanogromyza 
aeneoventris (Fallen) (Diptera: Agromyzidae) juga telah dibuktikan meningkat dengan meningkatnya keanekaragaman habitat di dalam lanskap (Kruess (2003). Keanekaragaman Hymenoptera pada lanskap sederhana (pertanaman padi monokultur) ternyata lebih rendah dibandingkan dengan keanekaragaman Hymenoptera pada lanskap kompleks yang terdiri atas habitat tumbuhan liar, sayuran, palawija, dan pertanaman padi (Yaherwandi et al. 2007).

Memahami pengaruh struktur lanskap terhadap komposisi, kelimpahan, dan keanekaragaman Hymenoptera sangat penting karena peran Hymenoptera sebagai agens hayati yang mampu menekan kerusakan tanaman oleh hama (LaSalle \& Gauld 1993). Penelitian ini bertujuan untuk mempelajari pengaruh struktur lanskap terhadap komposisi dan kelimpahan Hymenoptera parasitoid pada berbagai tipe lanskap pertanian di wilayah Bogor.

\section{BAHAN DAN METODE}

\section{Waktu dan lokasi penelitian}

Penelitian dilakukan dari bulan Januari sampai Desember 2016 di enam wilayah Bogor, yaitu di Desa Bantarjaya (06 ${ }^{\circ} 53^{\prime} 73.7^{\prime \prime}$ LS; 106 $6^{\circ} 73$ '51.0" BT), Bojong (06 52 '86.9” LS; 106 $75^{\prime} 37.8^{\prime \prime}$ BT),
Cibeureum (06 $\left.57^{\prime} 26.6^{\prime \prime} \mathrm{LS} ; 106^{\circ} 73^{\prime} 12.3^{\prime \prime} \mathrm{BT}\right)$, Cikarawang (0660'69.4" LS; 10669'97.2” BT), Gunungmenyan (06 $62^{\prime} 08.8^{\prime \prime}$ LS; 106 $66^{\prime}$ '97.6" BT), dan Petir (06 61'61.8" LS; 106 $71^{\circ} 99.7^{\prime \prime}$ " BT) (Gambar 1) yang memiliki struktur lanskap beragam dengan dominansi fragmen yang berbeda (Gambar 2).

Pada pertanaman kacang panjang pada masingmasing lanskap, dibuat plot berukuran $50 \mathrm{~m} \mathrm{x}$ $25 \mathrm{~m}$, dan dibuat jalur transek dengan panjang $50 \mathrm{~m}$ dengan jarak antar transek $5 \mathrm{~m}$. Sepanjang jalur transek ditentukan titik peng-ambilan sampel yang berjarak $1 \mathrm{~m}$ sehingga masing-masing transek terdapat 50 titik sampel, dan secara keseluruhan terdapat 200 titik sampel. Pengambilan sampel pada pertanaman kacang panjang, yaitu umur $7,14,21,28,35,42$, dan 49 hari setelah tanam (HST). Hal ini berdasarkan pertimbangan keadaan pertanaman dan tingkat pertumbuhan tanaman kacang panjang di lapangan.

\section{Karakterisasi dan kuantifikasi lanskap}

Struktur dan dominansi lanskap dihitung secara kuantitatif berdasarkan peta penutupan/ penggunaan lahan yang dibangun berdasarkan citra resolusi tinggi Google Earth dengan radius $500 \mathrm{~m}$ dari titik tengah kebun pada setiap lanskap. Jenis spesies yang ditanam dan penutupan/ penggunaan lahan di setiap lanskap pada radius

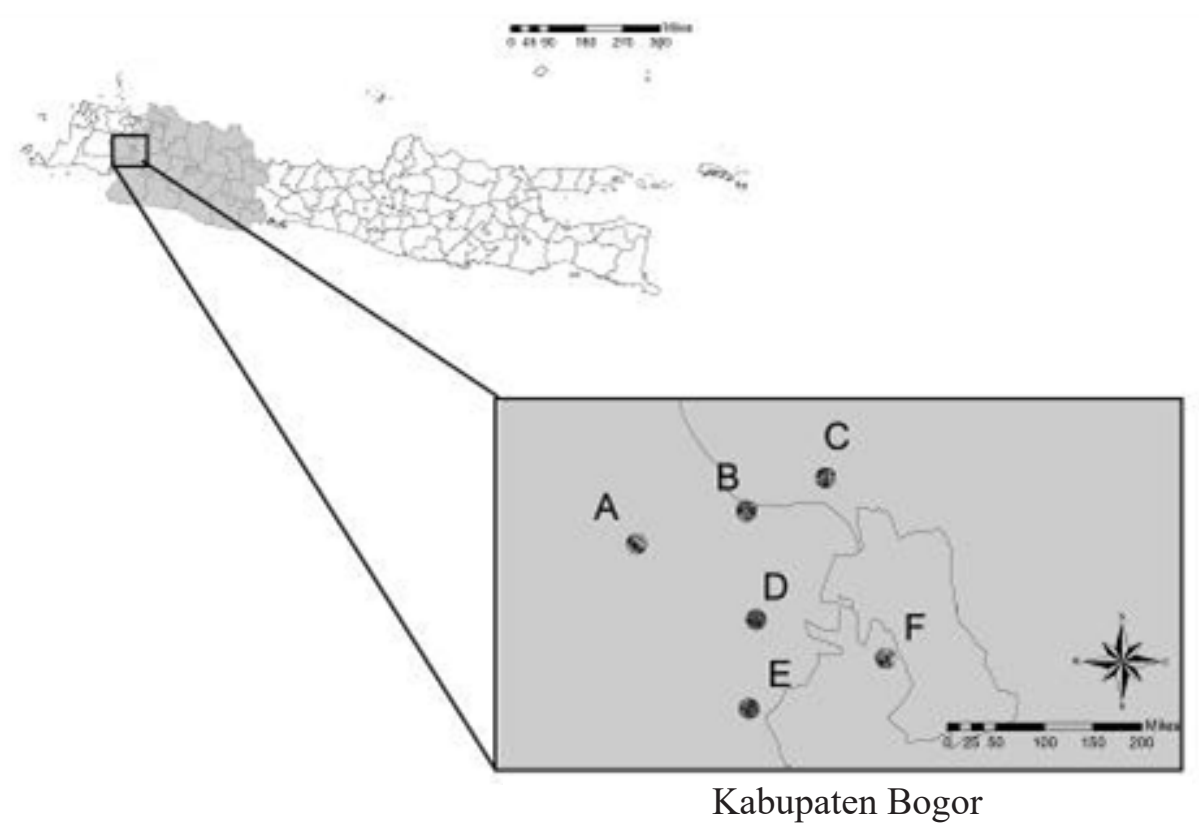

Gambar 1. Peta lokasi penelitian di Kawasan Bogor. A: Desa Bantarjaya; B: Desa Bojong; C: Desa Cibeureum; D: Desa Cikarawang; E: Desa Gunungmenyan; F: Desa Petir. 
$500 \mathrm{~m}$ ditentukan dengan survei lapangan. Parameter lanskap yang digunakan, untuk skala klas (class scale) adalah CA dan NumP dari lahan pertanian dan habitat pepohonan (semi-natural habitat); dan untuk skala lanskap adalah NumP, MPS, MSI, TE, dan MPFD. Analisis indeks lanskap dilakukan dengan menggunakan Fragstat (McGarigal \& Marks 1995).

\section{Pengambilan sampel serangga}

Pengambilan sampel serangga pada setiap titik sampel pada jalur transek dilakukan dengan menggunakan hand-collecting (pengambilan langsung). Hand-collecting merupakan metode pengambilan serangga langsung dengan tangan yang dikoleksi menggunakan cup plastik berukuran (alas $6,5 \mathrm{~cm} \times 5 \mathrm{~cm}$ dan tinggi $4,5 \mathrm{~cm}$ ), untuk setiap titik sampel (Heong et al. 1991). Pada penelitian ini menggunakan metode dari Ulina (2016), yaitu metode transek dengan pengambilan langsung untuk mendapatkan sampel secara menyeluruh dalam area penelitian berukuran $25 \mathrm{~m}$ x $50 \mathrm{~m}$ (Gambar 3). Pengambilan sampel dilakukan dengan hand-collecting akan lebih akurat menggambarkan parasitoid yang benarbenar menyerang hama pada kacang panjang.
Pengkoleksian serangga dengan mengumpulkan serangga inang pada stadia telur, larva, dan pupa. Serangga yang ditemukan dimasukkan ke dalam cup plastik dan diberi keterangan label berupa tanggal pengambilan, kode lokasi, dan kode transek. Serangga inang yang ditemukan di lapangan tersebut dipelihara di laboratorium untuk melihat terjadinya parasitisasi serta imago yang muncul. Imago yang muncul dimasukkan ke dalam microtube berisi alkohol $70 \%$ untuk kemudian diidentifikasi.

\section{Identifikasi serangga}

Identifikasi serangga dilakukan di Laboratorium Pengendalian Hayati, Departemen Hama dan Penyakit Tumbuhan, Fakultas Pertanian, IPB University. Semua serangga yang diperoleh dipisahkan berdasarkan ordo. Khusus bagi Ordo Hymenoptera parasitoid, identifikasi dilanjutkan sampai tingkat famili dan morfospesies (hanya diberi kode) selanjutnya, morfospesies disebut spesies. Identifikasi serangga untuk tingkat famili dilakukan dengan mengacu pada referensi Goulet \& Huber (1993), Wharton et al. (1997). Identifikasi tingkat morfospesies berdasarkan ciri morfologi dibandingkan dengan spesimen di Laboratorium

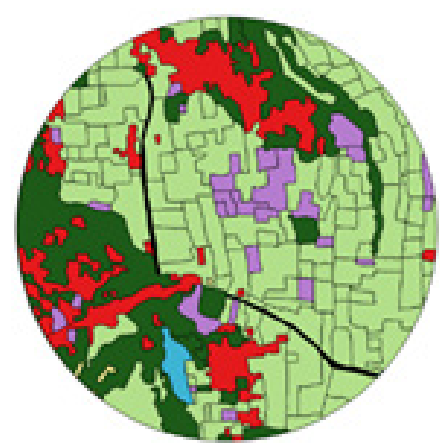

Bojong

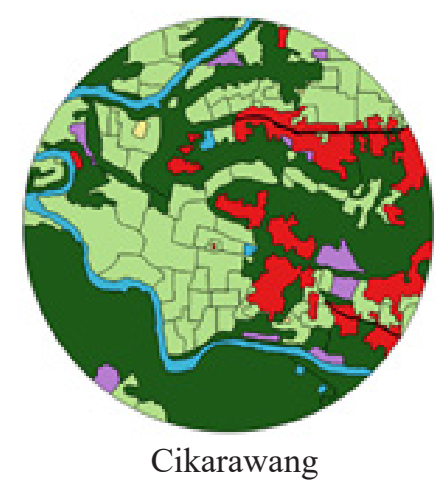

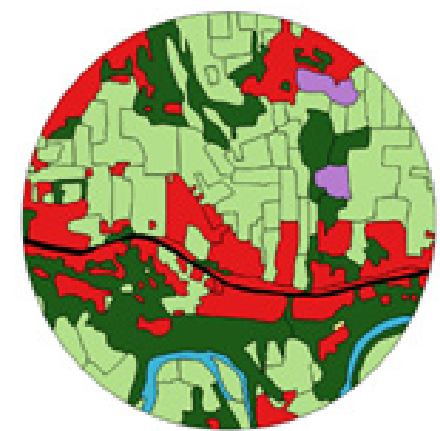

Bantarjaya

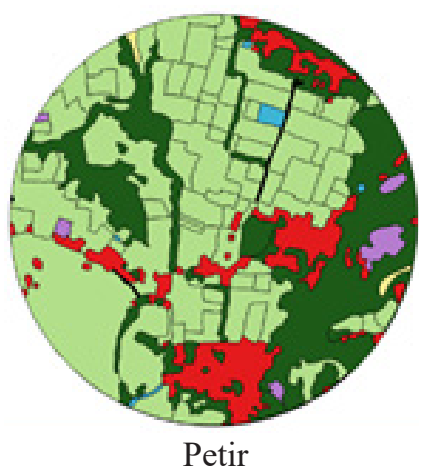

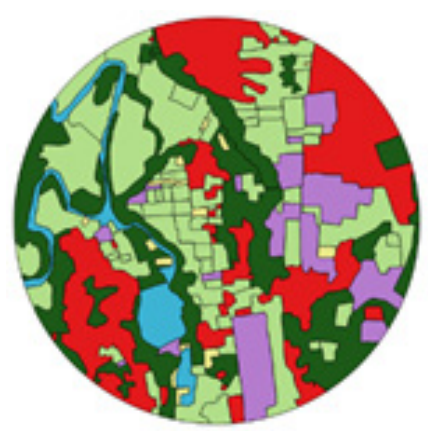

Cibeureum

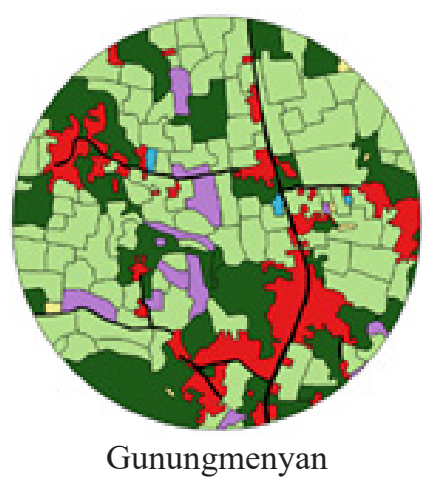

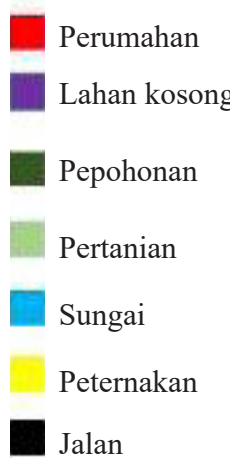

Jalan

Gambar 2. Peta penutupan dan penggunaan lahan dalam radius $500 \mathrm{~m}$ di enam lanskap. 
Entomologi, Museum Zoologicum Bogoriense, Lembaga Ilmu Pengetahuan Indonesia (LIPI), Bogor, Indonesia

\section{Analisis data}

Kemiripan struktur lanskap dan komposisi spesies Hymenoptera parasitoid pada keenam struktur lanskap digambarkan dalam bentuk dendogram dengan menggunakan euclidience distance untuk strutkur lanskap dan indeks Braycurtis untuk komposisi spesies Hymenoptera parasitoid. Mantel test digunakan untuk menguji hubungan antara struktur lanskap dan komposisi spesies Hymenoptera parasitoid. Analisis generalized linear model (GLM) juga dilakukan untuk mengetahui hubungan komposisi lanskap pada skala klas terhadap kelimpahan parasitoid. Seluruh analisis dikerjakan dengan menggunakan perangkat lunak R statistic (R Core Team 2020).

\section{HASIL}

Klasifikasi lanskap pertanaman kacang panjang pada enam wilayah di Bogor

Dari hasil pengelompokan berdasarkan struktur lanskap, yaitu NumP, MPS, MSI, TE, dan MPFD didapatkan dendogram pengelompokan kemiripan struktur lanskap dari setiap lokasi penelitian (Gambar 3A). Berdasarkan nilai jumlah fragmen (NumP) tertinggi maka lokasi Bojong memiliki jumlah fragmen terbesar, yaitu 208 fragmen, dan Gunungmenyan memiliki 187 fragmen (Tabel 1). Total edge (TE) tertinggi juga dimiliki oleh Bojong dan Gunungmenyan. Jumlah fragmen yang banyak dan nilai TE yang lebih tinggi mengindikasikan bahwa lanskap tersebut semakin beragam dan terfragmentasi dibandingkan dengan empat area lanskap lainnya sehingga dari analisa parameter tersebut tampaknya lanskap Gunungmenyan dan Bojong relatif lebih kompleks dibandingkan dengan keempat lanskap lainnya. Kawasan Bojong berada di daerah persawahan dikelilingi tanaman sayuran, sedangkan Gunungmenyan berada disekitar kawasan pepohonan (hutan sekunder) yang dikelilingi area persawahan (Gambar 4).

\section{Hubungan struktur lanskap dan keanekara- gaman Hymenoptera parasitoid}

Hasil koleksi Hymanoptera parasitoid dengan menggunakan keseluruhan metode diperoleh 283 individu parasitoid yang terdiri atas 31 morfospesies dan 9 famili. Parasitoid yang ditemukan meliputi dari kelompok parasitoid telur (Trichogrammatidae, Scelionidae, Mymaridae, dan Playtgastridae) dan juga parasitoid larva/ pupa. Jumlah spesies yang terbanyak didapatkan dari Famili Braconidae (Tabel 2). Microplitis manilae Ashmead (Famili Braconidae) merupakan spesies yang paling sering ditemukan pada semua lanskap. Parasitoid ini merupakan parasitoid larva dari hama Spodoptera litura Fabricius, sedangkan Therophilus marucae van Achterberg \& Long (Famili Braconidae) merupakan parasitoid Maruca vitrata Fabricius, yaitu hama polong pada kacang panjang (Gambar 5).

Berdasarkan analisis dendogram, komposisi spesies Hymenoptera parasitoid cenderung menunjukkan perbedaan antar lanskap pertanian (Gambar 3B) dan tidak memiliki hubungan dengan struktur lanskap (Mantel statistic $\mathrm{r}=0,013 ; \mathrm{P}=$ 0,481). Walaupun demikian, hasil analisis GLM menunjukkan bahwa komposisi lanskap pada skala klas mempengaruhi kelimpahan Hymenoptera parasitoid (Tabel 3). Semakin tinggi jumlah fragmen (NumP) dari lahan tanaman pertanian maka kelimpahan parasitoid menjadi semakin tinggi $(\mathrm{P}=0,02)$.

\section{PEMBAHASAN}

Dari enam kawasan agroekosistem di daerah Bogor, memiliki sturktur lanskap yang berbedabeda. Berdasarkan hasil kuantifikasi lanskap, Desa Bojong merupakan kawasan yang didominasi oleh persawahan dan tanaman sayuran. Desa Bantarjaya adalah area yang didominasi oleh pemukiman penduduk, Cibeureum berdekatan dengan area pekarangan dan pemukiman, Cikarawang berada dipinggir jalan desa dan ada pepohonan disekitarnya, sedang Desa Petir dikelilingi pesawahan. Desa Gunungmenyan berada dekat dengan area pepohonan (hutan sekunder) yang dikelilingi pesawahan. 


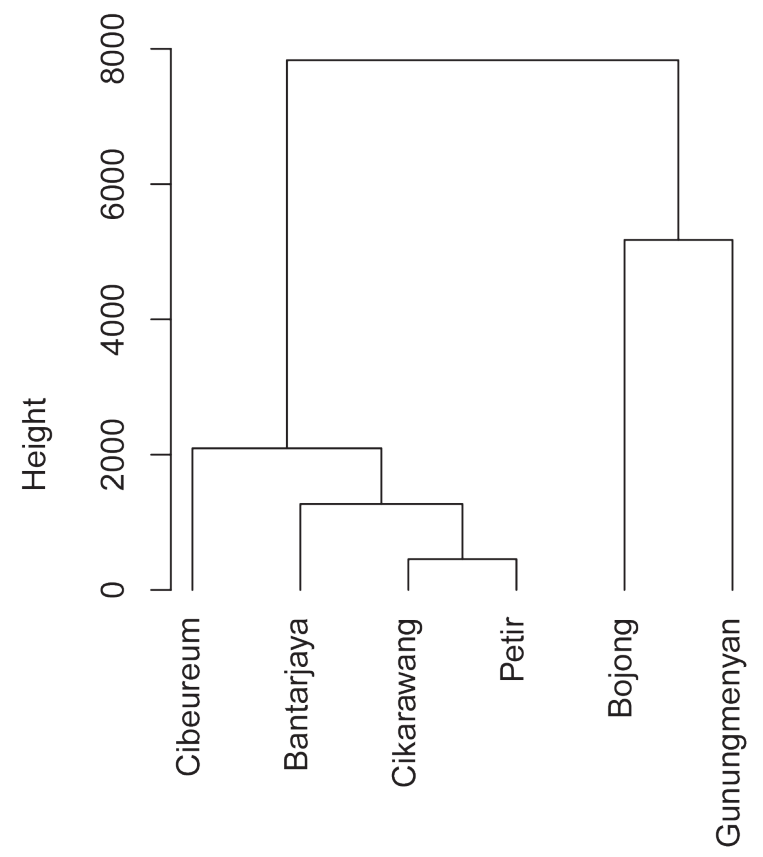

A

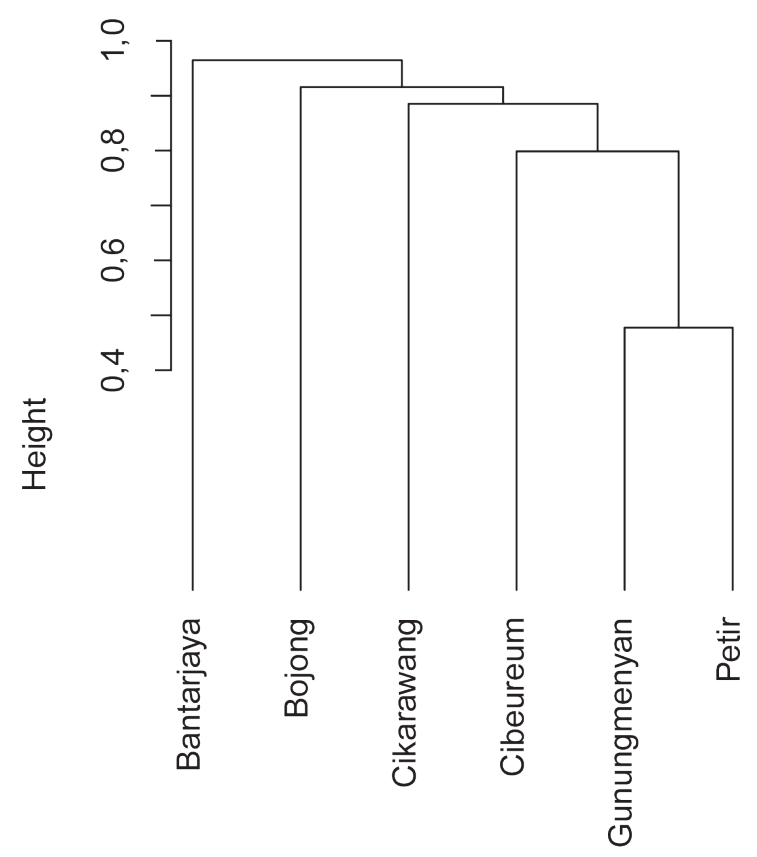

$\mathrm{B}$

Gambar 3. Dendogram pengelompokan kemiripan A: struktur lanskap dan B: komposisi spesies Hymenoptera parasitoid di enam lokasi penelitian. 
Tabel 1. Nilai parameter lanskap di enam lokasi penelitian di Bogor

\begin{tabular}{lccccc}
\hline Lanskap & NumP & MPS & MSI & TE & MPFD \\
\hline Bantarjaya & 152 & 0,60 & 1,80 & 58769 & 1,43 \\
Bojong & 208 & 0,66 & 1,71 & 67817 & 1,43 \\
Cibeureum & 149 & 0,57 & 1,62 & 55828 & 1,40 \\
Cikarawang & 145 & 1,31 & 1,99 & 57271 & 1,45 \\
Gunungmenyan & 187 & 0,61 & 1,73 & 62642 & 1,43 \\
Petir & 159 & 0,65 & 1,94 & 57726 & 1,46 \\
\hline
\end{tabular}

NumP: jumlah setiap jenis fragmen (number of patch); MPS: rata-rata luas fragmen yang sejenis (mean patch size); MSI: ratarata indeks bentuk fragmen (mean shape index); TE: total tepian (total edge); dan MPFD: rata-rata dimensi fraktal fragmen (mean patch fragtal dimension).

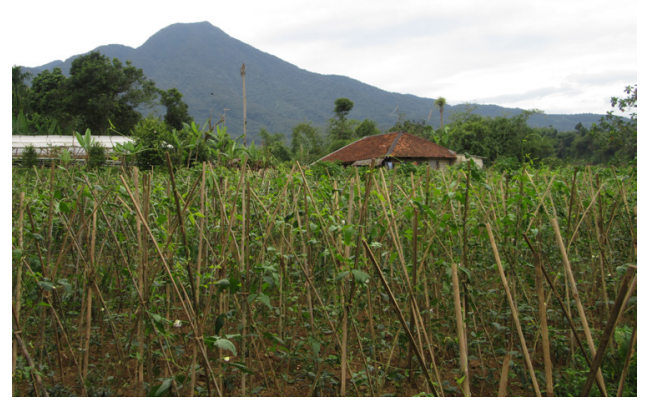

A

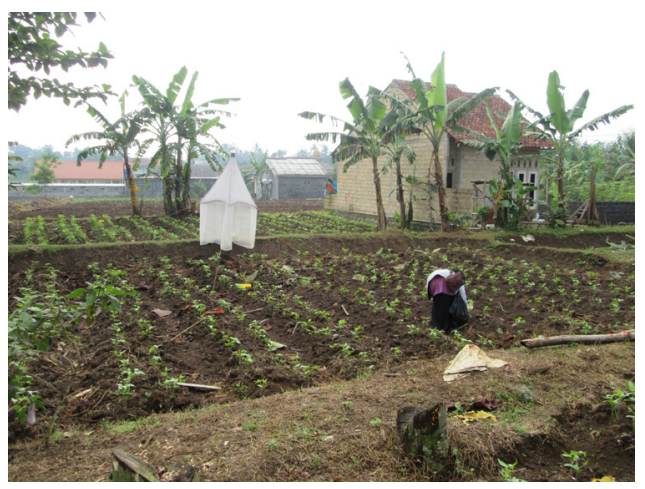

$\mathrm{C}$

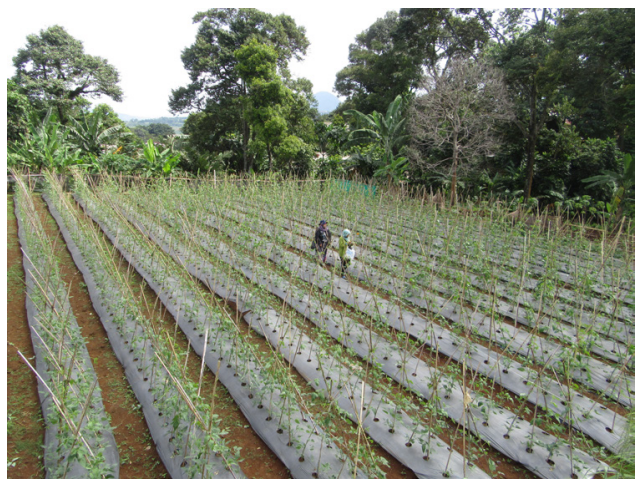

B

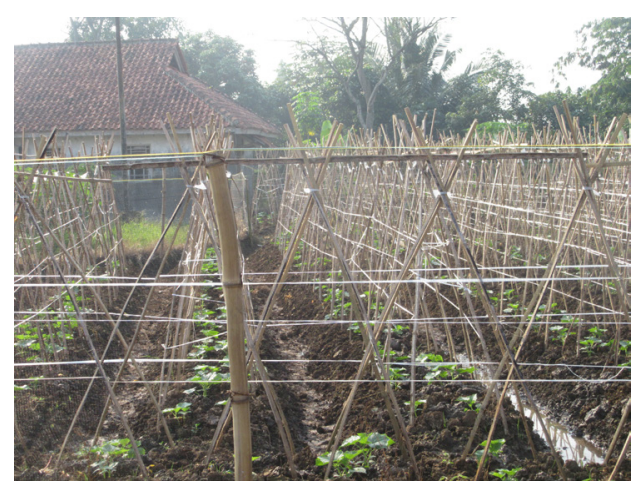

$\mathrm{D}$

Gambar 4. Lanskap pertanaman kacang panjang. A: Desa Gunnngmenyan; B: Desa Bojong; C: Desa Bantarjaya; D: Desa Petir.

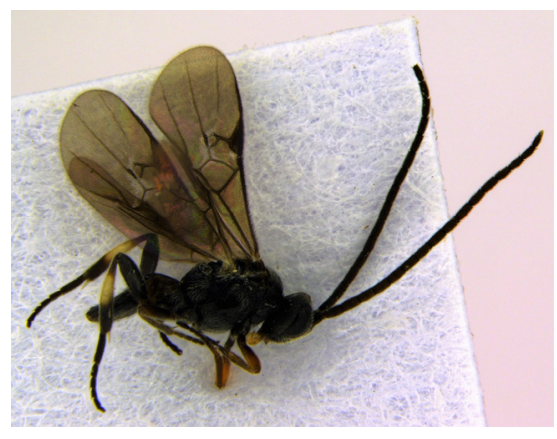

A

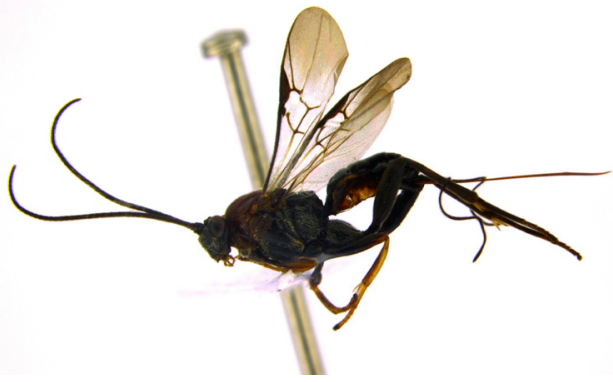

B

Gambar 5. Spesies parasitoid. A: Microplitis manilae dan B: Therophilus marucae. 
Tabel 2. Kekayaan dan kelimpahan morfospesies Hymenoptera parasitoid pada pertanaman kacang panjang di enam lokasi penelitian

\begin{tabular}{|c|c|c|c|c|c|c|}
\hline Morfospesies & Bantarjaya & Bojong & Cibeureum & Cikarawang & Gunungmenyan & Petir \\
\hline Braconidae sp1 & 1 & 0 & 1 & 1 & 14 & 10 \\
\hline Braconidae sp4 & 0 & 0 & 5 & 0 & 2 & 1 \\
\hline Braconidae sp5 & 0 & 0 & 0 & 0 & 1 & 2 \\
\hline Braconidae sp8 & 0 & 0 & 0 & 0 & 6 & 0 \\
\hline Microplitis manilae & 0 & 4 & 8 & 1 & 5 & 3 \\
\hline Therophilus marucae & 0 & 0 & 2 & 0 & 4 & 0 \\
\hline Ceraphronidae sp1 & 0 & 0 & 0 & 1 & 0 & 0 \\
\hline Elasmidae sp1 & 0 & 0 & 0 & 2 & 0 & 0 \\
\hline Encyrtidae sp1 & 0 & 0 & 0 & 0 & 1 & 0 \\
\hline Encyrtidae sp2 & 0 & 0 & 1 & 0 & 9 & 4 \\
\hline Encyrtidae sp3 & 0 & 0 & 1 & 0 & 0 & 0 \\
\hline Encyrtidae sp4 & 0 & 0 & 1 & 0 & 0 & 0 \\
\hline Encyrtidae sp5 & 0 & 0 & 6 & 0 & 7 & 0 \\
\hline Eulophidae sp1 & 0 & 0 & 0 & 0 & 3 & 0 \\
\hline Eulophidae sp2 & 0 & 0 & 0 & 9 & 3 & 0 \\
\hline Eulophidae sp3 & 0 & 0 & 1 & 0 & 1 & 0 \\
\hline Eulophidae sp4 & 0 & 0 & 1 & 1 & 0 & 0 \\
\hline Eulophidae sp5 & 0 & 2 & 0 & 0 & 2 & 0 \\
\hline Eulophidae sp6 & 0 & 0 & 6 & 0 & 0 & 0 \\
\hline Eulophidae sp7 & 0 & 0 & 0 & 0 & 2 & 0 \\
\hline Mymaridae sp 1 & 0 & 0 & 0 & 0 & 3 & 0 \\
\hline Mymaridae sp2 & 0 & 0 & 0 & 0 & 2 & 0 \\
\hline Mymaridae sp3 & 0 & 0 & 0 & 1 & 4 & 0 \\
\hline Platygastridae sp1 & 0 & 2 & 0 & 6 & 0 & 0 \\
\hline Scelionidae sp1 & 0 & 1 & 0 & 2 & 22 & 40 \\
\hline Scelionidae sp2 & 0 & 0 & 1 & 2 & 0 & 0 \\
\hline Scelionidae sp4 & 0 & 0 & 0 & 2 & 0 & 0 \\
\hline Scelionidae sp6 & 0 & 0 & 0 & 1 & 0 & 0 \\
\hline Trichogrammatidae sp1 & 0 & 0 & 0 & 0 & 1 & 0 \\
\hline Trichogrammatidae sp2 & 0 & 0 & 0 & 0 & 4 & 0 \\
\hline Trichogrammatidae sp3 & 0 & 53 & 0 & 0 & 1 & 0 \\
\hline Total individu & 1 & 62 & 34 & 29 & 97 & 60 \\
\hline Total spesies & 1 & 5 & 12 & 12 & 21 & 6 \\
\hline
\end{tabular}


Tabel 3. Analisis GLM hubungan kelimpahan parasitoid dengan class area (CA pepohonan) dan jumlah patch (NumP pepohonan), class area (CA pertanian) dan jumlah patch (NumP pertanian)

\begin{tabular}{lccc}
\hline \multirow{2}{*}{ Variable } & \multicolumn{3}{c}{ Kelimpahan parasitoid } \\
\cline { 2 - 4 } & Estimate & $\mathrm{SE}$ & $\mathrm{P}$ \\
\hline (Intercept) & 29,81 & 0,75 & 0,01 \\
CA pepohonan & $-1,05$ & 1,53 & 0,06 \\
NumP pepohonan & 6,77 & 2,74 & 0,12 \\
CA pertanian & 2,26 & 1,99 & 0,05 \\
NumP pertanian & 1,02 & 2,23 & 0,02 \\
\hline
\end{tabular}

Berdasarkan struktur lanskap tampak bahwa Desa Bojong dan Gunungmenyan mempunyai kecenderungan untuk lebih "kompleks" dibandingkan dengan yang lain karena lebih tarfragmentasinya areal tersebut (yang dapat dilihat dari nilai TE dan NumP). Kondisi ini ternyata didukung oleh kelimpahan parasitoid yang lebih tinggi pada kedua kawasan desa/lanskap tersebut. Analisa lebih lanjut menunjukkan bahwa jumlah fragmen lahan pertanian dan luasnya area pertanian berpengaruh terhadap kelimpahan parasitoid. Meskipun pada skala lanskap tidak ada perbedaan dalam kekayaan spesies dan kelimpahan individu parasitoid pada enam tipe lanskap yang berbeda, kelimpahan Hymenoptera parasitoid menunjukkan perbedaan pada skala klas khususnya dipengaruhi oleh jumlah fragmen dari lahan pertanian. Hal ini menunjukkan bahwa area pertanian memiliki peran penting dalam konservasi musuh alami, seperti yang ditemukan oleh Syahidah et al. (2020).

Di Indonesia, pola pertanaman sayur-sayuran pada umumnya menerapkan sistem monokultur pada level "patch/plot", tetapi jika dilihat pada tataran lanskap, tampak pola pertanaman yang kompleks. Hal ini dapat terjadi karena tanaman kacang panjang (atau hortikultur lainnya) seringkali ditanam setelah melakukan rotasi dengan tanaman sayuran yang lain sehingga kompleksitas lahan juga dapat dilihat dalam konteks waktu dan ruang. Chaplin-Kramer et al. (2011), menyebutkan adanya dua fenomena yang menyebabkan perbedaan lanskap (sederhana dan kompleks) dapat memengaruhi keanekaragaman Hymenoptera parasitoid (musuh alami). Pertama, lanskap kompleks dapat menurunkan kemampuan musuh alami dalam menemukan inangnya (karena tidak mudah untuk mencari inang pada lanskap yang lebih beragam). Kedua, adanya fenomena resources concentration hypothesis, yaitu adanya konsentrasi sumber daya yang menyebabkan herbivor akan lebih banyak terkumpul pada luasan tertentu (kepadatan meningkat) (Stephens \& Myers 2012). Terkonsentrasinya herbivor pada luasan tertentu akan berpengaruh pada kemampuan musuh alami untuk menemukan inangnya. Sejumlah penelitian sebelumnya melaporkan bahwa tingkat parasitisasi lebih tinggi pada lahan pertanian yang berukuran kecil (Bianchi et al. 2006; Fahrig et al. 2011; Segoli \& Rosenheim 2012). Di samping itu, parasitisasi juga berkorelasi positif dengan luas habitat (CA) pepohonan dan panjang pinggiran (TE) habitat pepohonan. Keberadaan habitat pepohonan pada areal pertanian memiliki peranan yang sangat penting karena menyediakan sumber daya bagi parasitoid, seperti inang alternatif, pakan bagi imago parasitoid, dan tempat berlindung pada saat masa bera (Landis et al. 2000; Gagic et al. 2015). Pinggiran habitat pepohonan merupakan pertemuan antara habitat pepohonan dan habitat lainnya sehingga pinggiran habitat pepohonan ini seringkali berperan sebagai koridor bagi sejumlah spesies serangga (Jauker et al. 2009). Menurut Krewenka et al. (2011) koridor pada lanskap yang terfragmentasi dapat meningkatkan kelimpahan dan kekayaan spesies parasitoid dan pada akhirnya memengaruhi populasi inang pada habitat alternatif. Jumlah patch memberikan informasi tentang fragmentasi yang terjadi di lanskap. Semakin banyak patch yang terbentuk, semakin besar pula fragmentasinya. 
Struktur lanskap dominan class area pertanian bila dicermati lebih detail terdiri atas berbagai habitat (beragam tanaman sayuran dan tumbuhan liar) sehingga membentuk lanskap mikro yang heterogen. Habitat-habitat tersebut menyediakan berbagai sumber makanan serangga dewasa, seperti nektar dan serbuk sari, sumber daya seperti inang alternatif, keadaan iklim mikro yang sesuai bagi kelangsungan hidup dan keanekaragaman parasitoid, kontinuitas ketersediaan makanan dan habitat tempat lain sebagai tempat berlindung. Semua sumber daya tersebut dapat diperoleh pada sistem pertanian dengan lanskap kompleks (polikultur) (Dryer \& Landis 1996; Dryer \& Landis 1997). Struktur lanskap yang didominasi class area pertanian yang dicirikan dengan tingginya proporsi habitat semi alami, merupakan habitat yang mampu menyediakan kebutuhan parasitoid baik pada stadia pra-dewasa maupun dewasa sehingga habitat alami ini berperan sebagai pemelihara keberadaan dan sarana penghasil parasitoid di lanskap pertanian (Parolin et al. 2012). Peningkatan populasi parasitoid dan parasitisasi tersebut berkorelasi positif dengan jumlah fragmen lahan pertanian dan panjang tepi/ pinggir pepohonan dan berkorelasi negatif dengan rata-rata luas fragmen pertanian.

\section{KESIMPULAN}

Keanekaragaman dan komposisi spesies Hymenoptera parasitoid menunjukkan perbedaan antar lahan kacang panjang, tetapi tidak dipengaruhi oleh struktur lanskap. Walaupun demikian pada skala klas, komposisi lanskap berupa jumlah fragmen dari lahan pertanian memiliki korelasi positif dengan kelimpahan Hymenoptera parasitoid. Hal tersebut menunjukkan bahwa Hymenoptera parasitoid lebih dipengaruhi komposisi lanskap pada skala klas dibandingkan skala lanskap.

\section{UCAPAN TERIMA KASIH}

Penelitian ini dibiayai oleh IPB University dan Direktorat Kementrian Riset Teknologi dan Pendidikan Tinggi (DIKTI), Pendidikan Magister menuju Doktor untuk Sarjana Unggul (PMDSU) Hibah Penelitian SK No. 136/SP2H/LT/DRPM/ IV/2017 dan Hibah Penelitian PMDSU SK No. 129/SP2H/PTNBH/DRPM/2018. Ucapan terima kasih disampakan kepada petani kacang panjang di Bogor yang telah memberikan akses ke lahan untuk penelitian ini serta staf Laboratorium yang telah membantu selama pengumpulan data penelitian ini.

\section{DAFTAR PUSTAKA}

Bianchi FJJA, Booij CJH, Tscharntke T. 2006. Sustainable pest regulation in agricultural landscapes: a review on landscape composition, biodiversity and natural pest control. Proceedings of the Royal Society B: Biological Sciences 273:1715-1727. doi: https://doi.org/10.1098/ rspb.2006.3530.

Chaplin-Kramer R, O'Rourke ME, Blitzer EJ, Kremen C. 2011. A meta-analysis of crop pest and natural enemy response to landscape complexity. Ecology Letters 14:922-932. doi: https://doi. org/10.1111/j.1461-0248.2011.01642.x.

Costamagna AC, Menalled FD, Landis DA. 2004. Host density influences parasitism of the armyworm Pseudaletia unipuncta in agricultural landscapes. Basic and Applied Ecology 5:347-355. doi: https://doi.org/10.1016/j. baae.2004.04.009

Dryer LE, Landis DA. 1996. Effect of habitat, temprature and sugar availability on longevity of Eriborus terebrans (Hymenoptera: Ichneumonidae). Environmental Entomology 25:1192-1201. doi: https://doi.org/10.1093/ ee/25.5.1192.

Dryer LE, Landis DA. 1997. Influence of noncrop habitat on distribution of Eriborus terebrans (Hym: Ichneumonidae) in cornfields. Environmental Entomology 26:924-932. doi: https://doi.org/10.1093/ee/26.4.924.

Fahrig L, Baudry J, Brotons L, Burel FG, Crist TO, Fuller RJ, Sirami C, Siriwardena GM, Martin JL. 2011. Functional landscape heterogeneity and animal biodiversity in agricultural landscapes. Ecology Letters 14:101-112. doi: https://doi. org/10.1111/j.1461-0248.2010.01559.x.

Gagic V, Bartomeus I, Jonsson T, Taylor A, Winqvist C, Fischer C, Slade EM, Steffan-dewenter I, Emmerson M, Potts SG, Tscharntke T, Weisser W, Bommarco R. 2015. Functional identity 
and diversity of animals predict ecosystem functioning better than species-based indices. Proceedings of the Royal Society B: Biological Sciences 282:20142620 doi: https://doi. org/10.1098/rspb.2014.2620.

Goulet H, Huber JT. 1993. Hymenoptera of the World: An Identification Guide to Families. Ottawa: Research Branch Agriculture Canada Publ.

Heong KL, Aquino GB, Barrion AT. 1991. Arthropod community structure of rice ecosystem in the Philippines. Bulletin of Entomological Research 81:407-416. doi: https://doi.org/10.1017/ S0007485300031977.

Jauker F, Dieko T, Schwarzbach F, Wolters V. 2009. Pollinator dispersal in an agricultural matrix: opposing responses of wild bees and hoverflies to landscape structure and distance from main habitat. Landscape Ecology 24:547-555. doi: https://doi.org/10.1007/s10980-009-9331-2.

Kruess A. 2003. Effect of landscape structure and habitat type on a plant-herbivor-parasitoid community. Ecography 26:283-290. doi: https:// doi.org/10.1034/j.1600-0587.2003.03402.x.

Kruess A, Tscharntke T. 2000. Species richness and parasitism in a fragmented landscape: experiments and field studies with insects on Vicia sepium. Oceologia 122:129-137. doi: https://doi.org/10.1007/PL00008829.

Krewenka KM, Holzschuh A, Tscharntke T, Dormann CF. 2011. Landscape elements as potential barriers and corridors for bees, wasps and parasitoids. Biological Conservation 144: 1816-1825. doi: https://doi.org/10.1016/j. biocon.2011.03.014.

Landis DA. 1994. Arthropod sampling in agricultural landscapes: Ecological consideration. Di dalam: Pedigo LP, Butin GD (Eds.) Handbook of Sampling Methods for Pests in Agriculture. hlm. 15-31. London: CRC Press. doi: https://doi. org/10.1201/9781003067900-3.

Landis DA, Wratten SD, Gurr G. 2000. Habitat management to conserve natural enemies of arthropod pests in agriculture. Annual Review of Entomology 45175-201. doi: https://doi. org/10.1146/annurev.ento.45.1.175.

LaSalle J, Gauld ID. 1993. Hymenoptera: Their diversity, and their impact on the diversity of other organisms. Di dalam: LaSalle J, Gaul ID (Eds.). Hymenoptera and Biodiversity. hlm. 1-26. London: CAB Int.

Marino PC, Landis DA. 2000. Parasitoid community structure: Implications for biological control in agricultural landscapes. Di dalam: Ekbon $\mathrm{B}$, Irwin ME, Robert Y (Esd.). Interchanges of Insects between Aagriculturan and Surrounding Landscapes. hlm. 183-193. Boston: Kluwer Academic Publishers. doi: https://doi. org/10.1007/978-94-017-1913-1_11.

McGarigal K, Marks BJ. 1995. Fagstats: Spatial Pattern Analysis Program for Quantifying Landscape Structure. General Technical Report PNW-GTR-351. Portland: U.S. Department of Agriculture, Forest Service, Pacific Northwest Research Station. doi: https://doi.org/10.2737/ PNW-GTR-351.

Parolin P, Bresch C, Desneux N, Brun R, Bout A, Boll R, Poncet C. 2012. Secondary plants used in biological control: a review. International Journal of Pest Management 58:91-100. doi: https://doi.org/10.1080/09670874.2012.659229.

Prasetyo LB. 2017. Pendekatan Ekologi Lanskap untuk Konservasi Biodiversitas. Bogor: Institut Pertanian Bogor.

R Core Team. 2020. R: A Language and Environment for Statistical Computing. Vienna, Austria: R Foundation for Statistical Computing.

Rizali A, Himawan T, Fitriani I, Rahardjo BT, Karindah S, Puspitarini RD, Sahari B. 2018. Effect of natural habitat on diversity of hemipteran predator in oil palm plantation. Jurnal Hama dan Penyakit Tumbuhan Tropika 18:75-82. doi: https://doi.org/10.23960/j. hptt.11875-82.

Segoli M, Rosenheim JA. 2012. Should increasing the field size of monocultural crops be expected to exacerbate pest damage? Agriculture, Ecosystems \& Environment 150:38-44. doi: https://doi.org/10.1016/j.agee.2012.01.010.

Stephens AEA, Myers JH. 2012. Resource concentration by insects and implications for plant populations. Journal of Ecology 100:923931. doi: https://doi.org/10.1111/j.13652745.2012.01971.x.

Susilawati, Buchori, D, Rizali A, Pudjianto. 2018. Pengaruh keberadaan habitat alami terhadap keanekaragaman dan kelimpahan serangga pengunjung bunga mentimun. Jurnal Entomologi Indonesia 14:152-161. doi: https:// doi.org/10.5994/jei.14.3.152.

Syahidah T, Akhmad R, Prasetyo LB, Pudjianto, Buchori D. 2020. Short Communication: Landscape composition alters parasitoid wasps but not their host diversity in tropical agricultural landscapes. Biodiversitas 21:1702-1706. doi: https://doi.org/10.13057/biodiv/d210452. 
Ulina ES, Rizali A, Pudjianto, Manuwoto S, Buchori D. 2016. Lepidopteran community aand its parasitoid on cucumber field in Bogor, Sukabumi and Cianjur District, West Java. Jurnal Hama dan Penyakit Tumbuhan Tropika 16:184-195. doi: https://doi.org/10.23960/j.hptt.216184-195.

Ulina ES, Rizali A, Manuwoto S, Pudjianto, Buchori D. 2019. Does composition of tropical agricultural landscape affect. Agricultural and Forest Entomology 21:318-325. doi: https://doi. org/10.1111/afe.12334.

Veres A, Petit S, Conord C, Lavigne C. 2013. Does landscape composition affect pest abundance and their control by natural enemies? A review.
Agriculture, Ecosystem and Environment 166: 110-117.

Wharton RA, Marsh PM, Sharkey MJ. 1997. Manual of the New World Genera of the Family Braconidae (Hymenoptera). Washington DC: International Society of Hymenopterists, .

Yaherwandi, Manuwoto M, Buchori D, Hidayat P, Prasetyo LB. 2007. Keanekaragaman hymenoptera parasitoid pada struktur lanskap pertanian berbeda di daerah aliran sungai Cianjur, Jawa Barat Jurnal Hama dan Penyakit Tumbuhan Tropika 7:10-20. doi: https://doi.org/10.23960/j. hptt.1710-20. 